\author{
Stanisław Żerko \\ https://orcid.org/0000-0002-3778-4502 \\ Akademia Marynarki Wojennej w Gdyni \\ Instytut Zachodni w Poznaniu
}

\title{
Niemcy wobec Włoch w pierwszej fazie II wojny światowej (wrzesień 1939 - czerwiec 1940 r.)
}

\begin{abstract}
Abstrakt: Cel studium stanowi przedstawienie polityki Niemiec wobec Włoch w okresie miedzy atakiem niemieckim na Polskę 1 IX 1939 r. a przystąpieniem Włoch do wojny 10 VI 1940 r. Był to okres trudny dla stosunków bilateralnych ze względu na decyzję Mussoliniego o nieprzystąpieniu do wojny (non belligeranza), mimo więzów sojuszniczych z Niemcami. Dodatkowe trudności wywołało zacieśnienie stosunków niemiecko-sowieckich, a zwłaszcza atak ZSRR na Finlandię. Poprawa stosunków niemiecko-włoskich nastąpiła dopiero w związku z wyrażaną przez Mussoliniego gotowością w miarę szybkiego przystąpienia do wojny.
\end{abstract}

Słowa kluczowe: Niemcy, Włochy, historia, II wojna światowa, stosunki międzynarodowe.

Abstract: The purpose of the study is to present the policy of Germany towards Italy in the period between the German assault on Poland on 1 September 1939 and the Italy's accession to war on 10 June 1940. It was a difficult period for the bilateral relations because of the Mussolini's decision not to join the war (non-belligeranza) despite alliances with Germany. Additional difficulties were caused by strengthening of the German-Soviet relations, especially the attack of the USSR on Finland. The German-Italian relations improved only after Mussolini expressed his readiness to join the war relatively quickly.

Key w or d s: Germany, Italy, History, World War II, International relations. 
„Kampanię polską" we wrześniu 1939 r. Niemcy prowadziły właściwie bez sojuszników. Gdy 3 IX 1939 r. Wielka Brytania i Francja ogłosiły, że znajdują się $\mathrm{w}$ stanie wojny z Niemcami, na froncie w Polsce u boku żołnierzy Wehrmachtu walczyły tylko oddziały słowackie. Mało kto spośród międzynarodowych komentatorów poważnie jednak traktował marionetkowe, całkowicie uzależnione od Berlina, utworzone pół roku wcześniej na żądanie Hitlera „Państwo Słowackie” jako prawdziwego sojusznika Niemiec ${ }^{1}$. Nic dziwnego, że międzynarodowa opinia publiczna oceniała udział Słowaków w Polenfeldzug jako wydarzenie o znaczeniu marginalnym. Istotne w wymiarze europejskim znaczenie miała bowiem postawa jedynego wówczas pod względem prawnomiędzynarodowym sojusznika Niemiec - faszystowskiej Italii, związanej z Rzeszą podpisanym 22 V 1939 r. tzw. paktem stalowym². Rację należy przyznać polskiemu znawcy dziejów faszystowskiej Italii, piszącemu, że „bodaj nigdy w nowożytnych dziejach Włoch stanowisko władz tego państwa nie wywoływało tak powszechnego zainteresowania, jak przez kilkanaście miesięcy, od lata 1939 r. poczynając"3.

Drugiego dnia wojny, nazajutrz po ogłoszeniu przez Rzym, iż Włosi walczyć u boku Niemców nie będa, został z Berlina wysłany telegram szyfrowy o następującej treści: „Podstawą stosunków niemiecko-włoskich jest całkowite i jednoznaczne uzgodnienie stanowisk między Führerem a Duce. Proszę, gdyby Pan był o to pytany, w ten sposób odpowiadać. Jakakolwiek krytyka postawy Włoch nie może mieć miejsca, a gdyby coś takiego zaszło, będzie to surowo karane. Proszę stosownie poinstruować podległych sobie urzędników. Ribbentrop"4. Wysłanie tego okólnika było najwyraźniej konieczne ze względu

${ }^{1}$ Formalnie rzecz biorąc, Słowacja nie była związana z Rzeszą traktatem sojuszniczym, lecz jedynie podpisanym w marcu 1939 r. „układem o ochronie”, który wasalną zależność Bratysławy od Berlina ubierał w dość dziwne ramy prawne. Niemcy na mocy tego układu gwarantowały Słowacji jej granice, ale nie zobowiązywały swego „podopiecznego” do wyruszenia na front w razie, gdyby Rzesza znalazła się w wojnie.

${ }^{2}$ Brak w historiografii szczegółowej monografii, kompleksowo analizującej stosunki niemiecko-włoskie w całym okresie II wojny światowej. Obszerny tom: W. Rauscher, Hitler und Mussolini. Macht, Krieg und Terror, Graz-Wien-Köln 2001 obejmuje okres 1922-1945, ale II wojnę światowa traktuje dość pobieżnie, a poza tym jest oparty na nader wąskiej podstawie źródłowej. Dysponujemy natomiast sporą liczbą opracowań cząstkowych. Nowe, odświeżające, lecz skrótowe ujęcie zob. Ch. Goeschel, Mussolini and Hitler. The Forging of the Fascist Alliance, New Haven-London 2018. W polskim piśmiennictwie skrótowy zarys relacji Berlin-Rzym w latach trzydziestych zawiera: S. Żerko, Niemiecka polityka zagraniczna 1933-1939, Poznań 2005; z kolei B. Koszel, Rywalizacja niemiecko-włoska w Europie Środkowej i na Batkanach w latach 1933-1941, Poznań 1987, omawia napięcia między Rzymem i Berlinem.

${ }^{3}$ S. Sierpowski, Niemcy $w$ polityce wtoskiej $w$ latach 1939-1940, w: idem, Studia $z$ historii Wtoch XX wieku, Poznań 2012, s. 357.

${ }^{4}$ Politisches Archiv des Auswärtigen Amts (dalej: PAAA) Berlin, Botschaft Rom (Quirinal) geheim, t. 59, Ribbentrop do ambasadora w Rzymie, 2 IX 1939. Depesza znajduje się w zespole ambasady w Rzymie, lecz zapewne był to okólnik, wysłany też do innych placówek. 
na mało pochlebne uwagi, jakie zaczęto kierować w Rzeszy pod adresem sojusznika z paktu stalowego. Krytyka ta do tego stopnia upowszechniła się, że na Wilhelmstrasse obawiano się, iż nawet niemieccy dyplomaci będą ja wyrażać wobec swych rozmówców z innych krajów.

Joachimowi von Ribbentropowi zależało, by za granica nie zapanowało przekonanie, że świeżej daty sojusz między dwoma dyktatorami praktycznie nie istnieje. Było to zadanie trudne, gdyż nawet najbliżsi współpracownicy Hitlera wypowiadali się o postawie Rzymu w sposób zdecydowanie negatywny. „Göring jest oburzony na Włochów. Nie zasługują na nic innego jak na pogardę"5 - notował w swym dzienniku Joseph Goebbels, najwidoczniej zgadzajacc się z tą ostrą opinią. Przeciętny Niemiec pamiętał zreszta, że ćwierć wieku wcześniej Italia, tworząca wraz z Niemcami i Austro-Węrami tzw. trójprzymierze, wbrew traktatowym zobowiązaniom po wybuchu I wojny światowej najpierw ogłosiła neutralność, a w 1915 r. weszła do wojny jako sojusznik Ententy. Mocno nieprzekonująco musiały zatem brzmieć przekazane 10 września na polecenie Ribbentropa słowa adresowane do ambasadora Włoch w Berlinie Bernarda Attolica, że tego rodzaju opinie to przypadki rzadkie i pojedyncze ${ }^{6}$. Ten wątek był zresztą odtąd stale obecny we wzajemnych stosunkach obu niby-sojuszników. Kilka tygodni później, pod koniec listopada Galeazzo Ciano czynił wymówki ambasadorowi Niemiec w Rzymie Hansowi Georgowi von Mackensenowi z powodu słów, jakie wygłosił na wydanym w Dreźnie bankiecie namiestnik Rzeszy w Saksonii Martin Mutschmann. W obecności włoskiego konsula lokalny hitlerowski dygnitarz oznajmił bez ogródek: „Mamy przyjaciół, którzy nas oszukuja”. Raport o tym incydencie dotarł do samego Benita Mussoliniego (zapewne zadbał o to jego zięć, coraz bardziej sceptyczny wobec Niemców hr. Ciano) i wywołał oburzenie Duce ${ }^{7}$.

Rzym podążał własną drogą. Polityki Włoch nie można sprowadzić do formuły klasycznej sacro egoismo czasów premiera Antonia Salandry (19141916), chociaż zdawano tam sobie doskonale sprawę z wszystkich zalet, jaka dawała rola ,języczka u wagi”. W deklaracji wydanej po południu 1 września Mussolini zastapił określenie „neutralność” nieznanym do tej pory, niejasnym terminem non belligeranza, co oznaczać miało jedynie nieuczestniczenie

5 J. Goebbels, Dzienniki, t. II: 1939-1943, oprac. E.C. Król, Warszawa 2013, s. 6, zapis z 6 IX 1939.

${ }^{6}$ PAAA Berlin, Büro Staatssekretär, Italien, 1, f. 483, Schmidt do Weizsäckera, 10 IX 1939.

7 G. Ciano, Dziennik 1937-1943, oprac. T. Wituch, Pułtusk 2006, s. 446 (26 XI 1939).

8 W literaturze polskiej precyzyjną rekonstrukcję polityki Włoch w pierwszych dwóch tygodniach II wojny światowej daje H. Batowski, Agonia pokoju i poczqtek wojny. Sierpień - wrzesień 1939, Poznań 1984, s. 298 i n. Podstawową monografią pozostaje: F. Siebert, Italiens Weg in den Zweiten Weltkrieg, Frankfurt a. M.-Bonn 1962 (studium oparte niestety jedynie na źródłach opublikowanych), na temat deklaracji z 1 września: ibidem, s. 345-356. Zob. W. Schütt, Der Stahlpakt und Italiens „Nonbelligeranza” 1938-1940, „Wehrwissenschaftliche Rundschau” 1958, nr 8, s. 498-521. 
w działaniach wojennych przy zachowaniu lojalności i życzliwości wobec sojusznika, a przede wszystkim „gotowość do skoku”, czyli do przystapienia do wojny. Uczynił tak nie tylko dlatego, że chciał ratować pozory ${ }^{10}$. Osobiście żałował, że Włochy nie staną zbrojnie u boku Niemiec i z ciężkim sercem musiał pogodzić się z faktem, że jego kraj nie jest przygotowany do wojny z zachodnimi mocarstwami ${ }^{11}$. Niemniej także on próbował wyzyskać sytuację i akceptował wysiłki Ciana, troszczącego się o w miarę dobre stosunki z Paryżem i Londynem. Odrzucić jednak należy interpretację, zgodnie z która doszło do swoistego podziału ról między Duce, dbającym o możliwie najlepsze relacje z Führerem, i włoskim ministrem spraw zagranicznych, troszczacym się o stosunki z Zachodem. Stanowisko Mussoliniego było znacznie bardziej złożone. Zdając sobie sprawę z nieprzygotowania Italii, będąc też świadomym korzyści płynących z lawirowania między znajdujacymi się $\mathrm{w}$ stanie wojny mocarstwami, włoski dyktator podświadomie czuł, że nieoczekiwane umiłowanie pokoju mocno kłóci się z ideologią faszyzmu. Musiał też jednak brać pod uwagę nastawienie opinii publicznej swojego kraju, Włosi bowiem en masse decyzję rządu w Rzymie o niewchodzeniu do wojny przyjęli z wielką ulgą.

Kierujący włoską dyplomacją zięć Mussoliniego tymczasem zdążył już wyleczyć się ze swego okazywanego kilka lat wcześniej entuzjazmu w sprawie zacieśnienia stosunków z Berlinem. Dzienniki hr. Ciana są dowodem zdecydowanej niechęci i do III Rzeszy, i do Hitlera, a zwłaszcza do Ribbentropa nawet przy zastrzeżeniu, iż w 1943 r. mogły zostać przez zdymisjonowanego już wówczas autora podkoloryzowane. Pisał w nich np., że jego wystapienie podczas posiedzenia rządu 1 września utrzymane zostało „w tonie otwarcie antyniemieckim" i z widoczną satysfakcją zaznaczał w swych zapiskach, że reakcje zgromadzonych były ,jak najlepsze” ${ }^{\prime 2}$. W każdym razie Ciano z upodobaniem realizował swego rodzaju politykę balansowania między formalnie

9 Italia „rzekomo gotowa do skoku” (angeblich sprungbereit) to określenie ze wspomnień ówczesnego sekretarza stanu w AA: E. von Weizsäcker, Erinnerungen, München-LeipzigFreiburg i. Br. 1950, s. 273.

${ }^{10}$ Krótkie ujęcie celów wojennych Mussoliniego w pracy cenionego amerykańskiego historyka: G.L. Weinberg, Wizje zwycięstwa. Nadzieje ośmiu przywódców z czasów drugiej wojny światowej, tłum. R. Dymek, Warszawa 2007, s. 63-78.

11 „Duce jest przekonany o konieczności zachowania neutralności, ale nie jest tym zachwycony” - zapisał Ciano w swym diariuszu 2 września. G. Ciano, op. cit., s. 415. Tego rodzaju cytatów można by przytoczyć znacznie więcej. Najbardziej charakterystyczna wypowiedź Mussoliniego pochodzi z 9 października: „Włosi - powiedział - wysłuchując od osiemnastu lat mojej wojowniczej propagandy, nie potrafia zrozumieć, jak mógłbym teraz, gdy Europa stoi w płomieniach, stać się heroldem pokoju. A przecież nie ma innego wyjaśnienia poza wojskowym nieprzygotowaniem kraju. Ale i za to można zrzucać odpowiedzialność na mnie, jako tego, który zawsze nawoływał do wzmocnienia naszych sił zbrojnych”. Ibidem, s. 434.

12 Ibidem, s. 414 (zapis z 1 IX 1939). Trzeba zaznaczyć, że wydana wcześniej w Polsce dwukrotnie $(1949,1991)$ wersja zatytułowana Pamiętniki 1939-1943 jest niekompletna, została przetłumaczona $\mathrm{z}$ angielskiego, a nie $\mathrm{z}$ oryginału włoskiego, i zawiera omyłki. 
sojuszniczymi Niemcami a Francją i Wielką Brytania, z jednoczesnym pozorowaniem sojuszniczej solidarności z prowadząca działania wojenne Rzesza. Co więcej, włoski minister dążył do poprawy relacji Rzymu z obydwiema zachodnioeuropejskimi stolicami i nawet udało mu się uzyskać pewne sukcesy pod tym względem. Nie miał w każdym razie problemów z wyrażaniem krytycznych opinii na temat polityki Berlina. Już 1 września Ciano w rozmowie z brytyjskim ambasadorem dał wyraz oburzeniu z powodu współdziałania Niemiec ze Związkiem Radzieckim, którego zwalczanie było przecież jednym z naczelnych zadań zarówno faszyzmu, jak i narodowego socjalizmu ${ }^{13}$. $\mathrm{Z}$ kolei niemieckiego ambasadora przekonywał rankiem 1 września, że liczy się $\mathrm{z}$,szybką i zdecydowaną interwencją mocarstw zachodnich, aktywnym udziałem USA [w wojnie] już $\mathrm{w}$ najbliższym czasie $\mathrm{z}$ wrogą względem Osi postawą znacznej części Ameryki Południowej”. Kontrastowało to z postawa samego Mussoliniego, który kilka godzin później wyrażał wobec ambasadora Mackensena całkowitą ufność w zwycięstwo Niemiec, nawet gdyby Polska uzyskała pomoc swych sojuszników. Obiecywał też spełnić prośbę Berlina, by wysłać do Rzeszy włoskich robotników (Niemcom chodziło zwłaszcza o wykwalifikowanych górników ${ }^{14}$.

Mussoliniemu zależało, by „w oczach niemieckiego ani też włoskiego narodu nie uchodzić za wiarołomcę"15. Rankiem 1 września połączył się telefonicznie z Attolicem, polecając swemu ambasadorowi w Berlinie uzyskanie od Hitlera telegramu zwalniającego Duce z zobowiązań sojuszniczych. Attolico niemal dosłownie wtargnał do gabinetu kanclerza na godzinę przed zapowiedzianym na 10.00 przemówieniem dyktatora w Reichstagu. Hitlerowi nie pozostawało nic innego, jak szybko - choć bez entuzjazmu - wyrazić zgodę ${ }^{16}$. Odpowiedź kanclerza została wysłana niemal natychmiast. W czterozdaniowej depeszy znalazły się ,serdeczne podziękowania” za „dyplomatyczne i polityczne wsparcie dla Niemiec” i słowa, że Berlin w obecnej sytuacji nie oczekuje „militarnego wsparcia ze strony Włoch", licząc na zrealizowanie swych zamierzeń własnymi siłami $^{17}$ (nawiasem mówiąc w tym też duchu, mocno aluzyjnie, nawiązał Hitler do tej kwestii w mowie wygłoszonej w Reichstagu tego samego przedpołudnia). Depesza ta, natychmiast ogłoszona we Włoszech, w Rzeszy nie została opublikowana, tak więc antywłoskie nastroje niemieckiej opinii publicznej nie opadały. W końcu, po tygodniu, Attolico prosił o publikację słów kanclerza, wskazując, że powinno to ograniczyć krytykę polityki Rzymu w społeczeństwie

${ }_{13}$ Documents on British Foreign Policy, 1919-1939 (dalej: DBFP), seria 3, t. VII, London 1954, dok. 677.

${ }^{14}$ Akten zur deutschen auswärtigen Politik 1918-1945 (dalej: ADAP), seria D, t. VII, Baden-Baden 1956, dok. 507.

${ }^{15}$ Ibidem.

${ }^{16}$ I documenti diplomatici italiani (dalej: DDI), seria VIII, t. XIII, Roma 1953, dok. 563.

${ }_{17}$ ADAP, D, VII, dok. 500. Tego dnia Hitler wysłał Mussoliniemu jeszcze jedną, dłuższa depeszę uzasadniająca atak na Polskę. Ibidem, dok. 504. 
niemieckim ${ }^{18}$. Niemniej Ribbentrop 10 września kazał przekazać włoskiemu ambasadorowi, że konieczność taka nie zachodzi, nastawienie niemieckiej opinii publicznej wobec Włoch było jakoby dobre, krytyczne uwagi to tylko „rzadkie, pojedyncze przypadki”, a pora na opublikowanie depeszy Führera do Duce nieodpowiednia ${ }^{19}$. Były to oczywiście puste słowa. Włosi zreszta ze swej strony również formułowali różnego rodzaju zarzuty pod adresem niemieckich partnerów, chociażby w sprawie rozpętania wojny już w 1939 r., a nie - jak się umawiano - kilka lat później, czy też w kwestii nieinformowania Rzymu o przygotowywanym pakcie o nieagresji z ZSRR ${ }^{20}$.

W kurtuazyjną formę ubrał też Hitler swą negatywną odpowiedź na podjętą przez Ciana - zresztą bez przekonania - próbę mediacji w toczącej się wojnie. Przedstawiona przez Attolica w Berlinie 2 września propozycja Mussoliniego zwołania (na wzór Monachium) nowej międzynarodowej konferencji została przez stronę niemiecką utrącona ${ }^{21}$. W wysłanym już wieczorem 3 września (a więc gdy Francja i Wielka Brytania znajdowały się od kilku godzin w stanie wojny z Rzesza) liście do Duce Hitler wyrażał wdzięczność za mediację, ale jednocześnie zaznaczał, że nie może dopuścić, by „ofiara krwi” żołnierza niemieckiego została zmarnowana wskutek „dyplomatycznych knowań”. Pisał Hitler: „Nadal jestem zdania, że - aczkolwiek maszerujemy teraz różnymi drogami - to jednak los nas łączy. Jeżeli narodowosocjalistyczne Niemcy zostana zniszczone przez zachodnie demokracje, to faszystowskie Włochy czekałyby ciężkie czasy. Osobiście cały czas zdawałem sobie sprawę z tego związku obu naszych reżimów i wiem, że Pan, Duce, myśli dokładnie tak samo" ${ }^{2}$. Zreszta samo przyjęcie ambasadora Attolica przez Hitlera tuż przed wyjazdem tego ostatniego na front, późnym wieczorem 3 września, oraz prośba o przekazanie Duce pozdrowień były gestami, które Mussolini docenił ${ }^{23}$.

$\mathrm{W}$ rozmowie $\mathrm{z}$ ambasadorem Mackensenem, który następnego dnia rankiem wręczał włoskiemu dyktatorowi list Hitlera, Mussolini dał wyraz niezadowoleniu w zwiąku ze słowami Hitlera o „maszerowaniu teraz różnymi drogami” i zapewnił, iż solidaryzuje się z Niemcami. Dodał, że Włosi jakoby wiązali ponad 400 tys. nieprzyjacielskich żołnierzy w rejonie Alp i w Afryce $^{24}$. Duce wyraźnie chciał, by jego partner wiedział, że jedynie niedostateczne przygotowanie wstrzymuje Rzym przed udziałem w wojnie po stronie Berlina.

\footnotetext{
${ }^{18}$ ADAP, D, VIII, dok. 23.

19 PAAA Berlin, Büro Staatssekretär, Italien, 1, f. 483, Schmidt do Weizsäckera, 10 IV 1939. Zob. DDI, dok. 138.

${ }^{20}$ ADAP, D, VIII, dok. 24, 68 i 148.

${ }^{21}$ H. Batowski, op. cit., s. 244 i n., jednak z wyolbrzymieniem roli Fritza Hessego.

${ }^{22}$ ADAP, D, VII, dok. 565. List doręczony został Mussoliniemu przez ambasadora Mackensena następnego dnia $\mathrm{w}$ godzinach porannych.

${ }^{23}$ G. Ciano, op. cit., s. 416 (3 IX 1939).

${ }^{24}$ ADAP, D, VIII, dok. 1.
} 
Kilka dni później, 9 września przekonywał niemieckiego attaché wojskowego, że obecnie Italia „wiąże od Somali, przez Tunis, Korsykę po Alpy 500-600 tys. Francuzów", natomiast gdyby Włochy weszły do wojny, pociagnęłoby to za sobą opowiedzenie się Grecji, Rumunii, Jugosławii czy Egiptu po stronie Wielkiej Brytanii ${ }^{25}$.

Wyraźnie niechętnie przyjęto też $\mathrm{w}$ Berlinie zapytania włoskie $\mathrm{w}$ sprawie możliwości zawarcia pokoju poprzez przedstawienie korzystnych warunków ewentualnemu polskiemu rządowi. Zresztą z rządem Rzeczypospolitej Italia formalnie nadal utrzymywała oficjalne stosunki, które wygasły dopiero $\mathrm{w}$ czerwcu następnego roku ${ }^{26}$.

Kilka ciepłych słów Hitler poświęcił Włochom i Mussoliniemu w przemówieniu wygłoszonym w gdańskim Dworze Artusa 19 września. Z kolei Ribbentrop w bardzo serdecznym tonie rozmawiał z Cianem, dzwoniąc doń ze znajdującego się już w Polsce pociagu specjalnego. Niemniej w wielu sprawach Włochów trzymano na dystans, co wywoływało u tych ostatnich spore rozdrażnienie. Attolico np. już 18 września mówił zastępcy Ribbentropa, że jego rząd w obliczu praktycznego zakończenia „kampanii polskiej” pragnąłby wiedzieć, jakiego rodzaju twór quasi-państwowy Niemcy chcieliby powołać na obszarze dawnej II Rzeczypospolitej. Ambasador Włoch zaznaczał, że jego rząd nie chciałby dopiero $\mathrm{z}$ gazet dowiedzieć się o podjętych decyzjach ${ }^{27}$.

W Rzymie panowała też dezorientacja, gdy w Berlinie ogłoszono druga podróż Ribbentropa do Stalina i Wiaczesława Mołotowa. 26 września Attolico skarżył się na Wilhelmstrasse, że minister Ciano informację, iż Ribbentrop ponownie leci do Moskwy, otrzymał nie od Niemców, lecz z włoskiej ambasady w ZSRR. Attolico pytał nawet, czy to prawda, jakoby Ribbentrop tym razem miał na Kremlu podpisać niemiecko-radziecki sojusz wojskowy ${ }^{28}$. Następnego dnia zastępca Ribbentropa Ernst von Weizsäcker mówił Włochowi, że nic mu nie wiadomo o tego rodzaju sojuszu, chociaż ma miejsce „paralelność wojskowych operacji” wojsk niemieckich i radzieckich na ziemiach polskich. Zaprzeczał też zdecydowanie (,to fantazja”), jakoby Berlin porozumiał się z Moskwą w sprawie Rumunii: „Jesteśmy jak najdalsi od tego, by chcieć zakłócić panujący obecnie na Bałkanach spokój, zwłaszcza zaś w kwestii Rumunii”29. W związku z tym na zapytanie Attolica, czy Berlin miałby coś przeciwko temu, aby Włochy przystapiły do montowania „bloku ekonomiczno-politycznego

\footnotetext{
${ }^{25}$ Ibidem, dok. 37.

${ }^{26}$ O tym S. Sierpowski, Stosunki polsko-włoskie 1918-1940, Warszawa 1975; K. Strzałka, Między przyjaźniq a wrogościq. Z dziejów stosunków polsko-włoskich (1939-1945), Kraków 2001.

${ }^{27}$ PAAA Berlin, Büro Staatssekretär, Italien, 1, f. 483, notatka Weizsäckera z 18 IX 1939. Sekretarz stanu dodawał, że z podobnymi pytaniami zwracał się do niego również ambasador Japonii, ten jednak nie czynił tego w tak uporczywy sposób, jak Attolico.

${ }^{28}$ Ibidem, notatka Woermanna z 26 IX 1939.

${ }^{29}$ Ibidem, notatka Weizsäckera z 27 IX 1939.
} 
neutralnych państw dunajsko-bałkańskich oraz Hiszpanii" ${ }^{30}$, Wilhelmstrasse nie zgłosiło zastrzeżeń. Dodajmy, że koncepcja ta była osobista inicjatywa Ciana, wobec której - jak szef włoskiej dyplomacji zaznaczał na kartach swego diariusza - jego teść pozostawał mocno sceptyczny.

Włoski minister spraw zagranicznych utrzymywał wówczas żywy kontakt $\mathrm{z}$ ambasadorami dwóch zachodnioeuropejskich mocarstw prowadzacych wojnę z Niemcami. Z kolei w rozmowach z ambasadorem Rzeszy Cianem nie ukrywał swego pesymizmu w ocenie sytuacji, nawet gdy kampania w Polsce była już praktycznie zakończona. Ambasadorowi Mackensenowi mówił, że jego zdaniem Francja i Wielka Brytania nie wycofaja się z wojny. Powtarzał, że należy liczyć się też z włączeniem się do wojny Stanów Zjednoczonych. Sceptyczny był również w kwestii, jakie stanowisko zajmie Tokio, a aktualnego szefa japońskiej dyplomacji zięć Mussoliniego określił mianem bardzo proamerykańskiego ${ }^{31}$. Niemcy zresztą odnotowywali, że podpisanie przez nich traktatu o granicy i przyjaźni z ZSRR (28 września) ocenione zostało przez włoską opinię publiczną bardzo krytycznie.

30 września Ribbentrop kolejny raz połączył się telefonicznie ze swym włoskim odpowiednikiem, proponując spotkanie obu dyktatorów, wizytę Ciana w Berlinie lub przynajmniej rozmowę obu ministrów spraw zagranicznych na Brennerze. W efekcie 1 i 2 października doszło do dwudniowej wizyty Ciana w stolicy Rzeszy i długiej, dwuipółgodzinnej rozmowy z Hitlerem. Niewiele z niej wynikało, niemniej kanclerz wyraźnie chciał, by włoski gość wrócił do siebie $\mathrm{z}$ wiarą $\mathrm{w}$ zwycięstwo Niemiec $\mathrm{w}$ dalszej fazie wojny. Führer podkreślał przy tym, że w wojnie z zachodnimi demokratycznymi mocarstwami rozstrzygnie się nie tylko los Rzeszy, lecz również faszystowskiej Italii. Gdy Ciano przedstawiał płynące dla Niemiec korzyści z włoskiej non belligeranza, Hitler nie zaprzeczał. Skorzystał jednak z okazji, by zauważyć, że w stosownym momencie Rzym mógłby wejść do wojny przeciwko Francji i Wielkiej Brytanii. Kwestię ewentualnego kompromisowego pokoju potraktował zdawkowo. Niemniej, co z włoskiego punktu widzenia było dość istotne, zaakceptował projekt Ciana utworzenia bloku państw neutralnych pod egidą Rzymu ${ }^{32}$. Nie oznaczało to jednak, że włoska inicjatywa zostanie potraktowana przez Berlin przychylnie. Przeciwnie, wkrótce dała o sobie znać nieufność strony niemieckiej ${ }^{33}$.

${ }^{30}$ G. Ciano, op. cit., s. 430 (28 IX 1939). O koncepcji tej zob. F. Marzari, Projects for an Italian-led Balkan Bloc of Neutrals, September-December 1939, „Historical Journal” 1970, nr 13, s. 767-788.

${ }^{31}$ PAAA Berlin, Büro Staatssekretär, Der Krieg, 4, f. 779, Mackensen do AA, 29 IX 1939.

${ }^{32}$ ADAP, D, VIII, dok. 176; DDI, seria IX, t. I, dok. 552; G. Ciano, op. cit., s. 431-432. Jak zanotował Goebbels, Hitler był „z Ciano bardzo zadowolony”, ale w innym miejscu minister zauważył, że Włoch „dostał ostrą reprymendę”. J. Goebbels, op. cit., t. II, s. 21.

33 Już kilkanaście dni później Ciano czuł się zmuszony prosić Niemców, by ci zdementowali powtarzane przez niemiecką agencję prasową DNB sugestie prasy brytyjskiej, jakoby Włochy próbowały stworzyć ugrupowanie państw neutralnych głównie po to, by zdystansować się od sojuszu z Rzeszą. ADAP, D, VIII, dok. 266. 
Włoskiemu ministrowi wspominał Hitler również, że zamierza wystapić - co Ciano najpewniej przyją z dużym zadowoleniem - z inicjatywa pokojowa. Ten szeroko przez niemiecka propagandę upowszechniony „,apel o pokój” zawarty został w przemówieniu wygłoszonym przez kanclerza na forum Reichstagu 6 października, nazajutrz po ostatecznym wygaśnięciu regularnego oporu wojsk polskich. Proponując zawarcie kompromisowego pokoju z Francja i Wielką Brytanią przy konferencyjnym stole, sugerował nawet możliwość utworzenia jakiegoś mocno okrojonego pod względem terytorialnym państwa polskiego, co było odpowiedzia na sugestie wyrażone przez Ciana podczas jego niedawnej wizyty w Berlinie ${ }^{34}$. Oferta została odrzucona 10 października przez Francję, a dwa dni później przez Wielką Brytanię. Hitler zresztą sam nie wierzył, że jego propozycje zostana przyjęte, ponieważ już 9 października wydał „Dyrektywę nr 6”, w której mowa była o „rozbiciu Francji i rzuceniu Anglii na kolana" - to ostatnie sformułowanie oznaczać miało skierowanie Brytyjczyków z powrotem na Wyspy.

Niemcy wciaż słyszeli od swych włoskich partnerów przestrogi przed zbytnim zbliżeniem ze Związkiem Radzieckim. Mussolini bardzo ostro oceniał bolszewików i samego Stalina w rozmowie z ambasadorem Mackensenem 6 października ${ }^{35}$. Stosunki włosko-niemieckie wchodziły wówczas, w jaskrawym przeciwieństwie relacji między Berlinem a Moskwa, w stadium rosnącego napięcia ${ }^{36}$.

Nie brakowało też innych zakłóceń w stosunkach między dwoma formalnymi wprawdzie, ale mimo wszystko sojusznikami. Przedłużały się negocjacje w sprawie wysiedlenia ludności niemieckiej z włoskiej Górnej Adygi (niemiecki Południowy Tyrol), a na miejscu dochodziło do incydentów. Rokowania opóźniały się z powodu trudności w uregulowaniu spraw własnościowych. Ciano mówił (także, w otwarty sposób, ambasadorowi Mackensenowi), że Niemcy domagają się nawet „prawa wywozu - mówiąc poważnie - klamek i zamków do drzwi" "37. Układ w sprawie wysiedlenia Niemców z Górnej Adygi został w końcu podpisany 21 października ${ }^{38}$, później jednak do Berlina dotarły informacje, że Mussolini jest poirytowany wolnym tempem wyjazdów ludności niemieckiej ${ }^{39}$.

Wzajemne stosunki gospodarcze także nie układały się w sposób gładki. $\mathrm{Na}$ życzenie Niemiec z Włoch napływały wprawdzie do Rzeszy kolejne tysiące włoskich robotników, mających zastapić powołanych do służby wojskowej pracowników niemieckich, ale już w sprawie dostaw surowców za pośrednictwem

\footnotetext{
${ }^{34}$ Zwraca na to uwagę K. Strzałka, op. cit., s. 101 i n.

${ }^{35}$ ADAP, D, VIII, dok. 205.

${ }^{36}$ F. Siebert, op. cit., s. 372 i n.

${ }^{37}$ G. Ciano, op. cit., s. 435 (11 X 1939). Niemal identyczne sformułowanie („nawet klamek do drzwi” - „bis hinunter zur Türklinke”) w raporcie Mackensena z rozmowy z Cianem. ADAP, D, VIII, dok. 244.

38 Tekst: Dokumente der Deutschen Politik, t. VII, cz. 2, Berlin 1941, s. 641-653.

${ }^{39}$ ADAP, D, VIII, dok. 382.
} 
Włoch, z obejściem brytyjskiej blokady, strona niemiecka była mocno nieusatysfakcjonowana. Omawiajacy w Rzymie te kwestie w połowie października 1939 r., odpowiedzialny za kwestie ekonomiczne wysoki urzędnik Auswärtiges Amt Karl Clodius raportował, że Włosi wyraźnie obawiaja się negatywnej reakcji Wielkiej Brytanii ${ }^{40}$. Mussolini kazał zapewnić niemieckiego wysłannika, że władze włoskie uczynią wszystko, by ułatwić ten tranzyt, ale także on podkreślał, iż Rzym nie może ryzykować otwartego konfliktu z Londynem. Z kolei Ciano przekonywał Clodiusa, że Włosi uważają poczynienie tego rodzaju ułatwień wręcz za swój obowiązek wobec Niemiec, a stosowne zarządzenia zostały już na polecenie Duce wydane, ale w grę moga wchodzić jedynie te dostawy, które da się zamaskować w papierach (chodziło o statki transportowe poddawane brytyjskiej kontroli). Przy okazji Ciano poinformował, że Mussolini nie zgadza się z pomysłem swego ambasadora w Berlinie, by Italia zorganizowała protest grupy państw neutralnych przeciwko brytyjskim zarzadzeniom w sprawie morskiej blokady Niemiec. Wyjaśnienia Ciana, że Rzym nie chce być traktowany jak pozostałe kraje neutralne, gdyż w wypadku Włoch neutralność nie jest terminem, jaki może znaleźć zastosowanie w przypadku włoskiej non belligeranza ${ }^{41}$, brzmiały cokolwiek faryzejsko.

Kolejnym powodem zakłóceń w stosunkach niemiecko-włoskich była postawa Niemiec wobec ZSRR w okresie tzw. wojny zimowej. Ciano notował w swym dzienniku: „w żadnym razie nie możemy mieć złudzeń: postawa narodu włoskiego jest coraz bardziej antyniemiecka. Również rozkwitający u nas antybolszewizm pełni wyłącznie funkcję antygermanizmu". Dodawał przy tym cynicznie: „Los Finów byłby Włochom całkowicie obojętny, gdyby Rosjanie nie byli - w praktyce - sojusznikami Niemiec" 4 .

Agresja radziecka na Finlandię wywołała w Italii wielkie oburzenie, dochodziło nawet do antyradzieckich i profińskich manifestacji studentów ${ }^{43}$. Reakcja Kremla na te spontaniczne demonstracje było odwołanie nowo mianowanego ambasadora w Rzymie, Nikołaja Goriełkina, który nie zdążył nawet złożyć królowi Wiktorowi Emanuelowi III listów uwierzytelniających ${ }^{44}$. W kontaktach

40 Ibidem, dok. 260.

${ }^{41}$ Ibidem, dok. 277.

${ }^{42}$ G. Ciano, op. cit., s. 448 (3 XII 1939).

${ }^{43} \mathrm{Na}$ przykład w Genui 4 grudnia policja musiała rozproszyć wiec studentów chcących protestować przeciwko ZSRR na jednym z głównych placów miasta. PAAA Berlin, Botschaft Rom (Quirinal) geheim, t. 59, konsulat generalny w Genui do ambasady w Rzymie, 7 XII 1939. Z kolei podczas podobnego wiecu w Mediolanie policja zachowywała się bezczynnie. Ibidem, konsulat generalny w Mediolanie do ambasady w Rzymie, 5 XII 1939. O demonstracjach włoskich studentów także G. Ciano, op. cit., s. 449 (4 XII 1939) z komentarzem: „Nie należy [...] zapominać, że ludzie krzyczą «śmierć Rosji», ale myślą «'śmierć Niemcom»”.

${ }^{44}$ ADAP, D, VIII, dok. 494; G. Ciano, op. cit., s. 451 (9 XII 1939): „poinformowałem o tym Duce, podkreślając niezwykłą niegrzeczność podobnego gestu”. Goriełkina jednak pozostawiono w Rzymie, gdzie pełnił urząd ambasadora do 22 VI 1941 r., gdy Włochy wypowiedziały wojnę ZSRR. 
dyplomatycznych Włosi formułowali swe wątpliwości w powściagliwej formie, ale nawet wtedy dawali wyraz rozczarowaniu i zaniepokojeniu. Sam Mussolini w rozmowie $\mathrm{z}$ ambasadorem Mackensenem podkreślił 2 grudnia, że ekspansja ZSRR spowodować może katastrofalne skutki, a „dla Włoch bolszewizm pozostaje wrogiem numer jeden". Mówiąc o Sowietach, twierdził, że „chciwość tych szubrawców [włoski dyktator użył niemieckiego słowa Schieber] jest nienasycona" ${ }^{45}$. Inny niemiecki dyplomata odnotował słowa jednego z włoskich dygnitarzy: „My Włosi zdajemy sobie sprawę z tego, że ta wojna nie zostanie wygrana ani przez Anglię czy Francję, ani przez Niemcy, lecz ostateczne zwycięstwo należeć będzie do radzieckiej Rosji”"46. Kwaśno przyjęli Włosi zatrzymanie w Niemczech i odesłanie z powrotem za Alpy pociagu wiozącego do Finlandii zamówionych wcześniej przez Finów sześć włoskich samolotów wojskowych. Na próżno proszono stronę niemiecka, by wynalazła jakiś trick prawny, aby maszyny te mogły zostać przepuszczone przez terytorium Rzeszy ${ }^{47}$. W rozmowie z zastępcą Ribbentropa von Weizsäckerem 12 grudnia włoski chargé d’affaires a.i. oświadczył bez ogródek, że cieszy go każdy włoski samolot wykorzystywany podczas tej wojny po stronie fińskiej ${ }^{48}$. Tuż przed świętami Bożego Narodzenia ambasador Attolico w rozmowie z Weizsäckerem podkreślał, że antykomunizm ma dla ideologii faszystowskiej znaczenie fundamentalne i przestrzegał, że w razie gdyby z winy Moskwy doszło do „wzniecenia pożaru na Bałkanach”, wówczas Włochy zwróciłyby się przeciwko Związkowi Radzieckiemu, choć myśli tej ambasador nie chciał rozwijać ${ }^{49}$. Tydzień później Attolico prosił Weizsäckera o przekazanie Ribbentropowi, że w świetle włoskich ocen należy liczyć się wiosna z zajęciem przemoca przez ZSRR rumuńskiej Besarabii ${ }^{50}$. Wprawdzie wpływowy szef Niemieckiego Frontu Pracy Robert Ley podczas swej wizyty w Rzymie sygnalizował w rozmowie z Cianem 5 XII 1939 r., „że Niemcy przewiduja, iż w ciagu kilku lat dojdzie do konfliktu z Sowietami" "51, ale znany z kompromitujących ekscesów alkoholowych dygnitarz nie był osobistościa nazbyt poważana nawet wśród prominentów III Rzeszy.

Bardzo źle przyjęto w Niemczech przemówienie wygłoszone 16 grudnia przez Ciana w Izbie Faszystowskiej i Korporacyjnej. Zdecydowanie antykomunistyczne, przepojone, jak zanotował on w swym dzienniku, „subtelnym

\footnotetext{
${ }^{45}$ ADAP, D, VIII, dok. 410.

${ }^{46}$ PAAA Berlin, Botschaft Rom (Quirinal) geheim, t. 59, notatka radcy Spaklera z 1 XII 1939. Rozmówcą Spaklera był sekretarz stanu w Ministerstwie Korporacji Tullio Cianetti.

${ }^{47}$ PAAA Berlin, Büro Staatssekretär, Italien, 2, f. 487, notatki Woermanna i Wiehla z rozmów z Magistratim i Attolico z okresu 13 XII 1939 - 13 I 1940.

${ }^{48}$ Ibidem, Finnland, 1, f. 229, notatka Weizsäckera z 12 XII 1939.

${ }^{49}$ Ibidem, Aufzeichnungen über Diplomatenbesuche, t. 5, f. 1530, notatka Weizsäckera z 23 XII 1939.

${ }^{50}$ Ibidem, notatka Weizsäckera z 30 XII 1939.

${ }^{51}$ G. Ciano, op. cit., s. 450 (5 XII 1939).
} 
antyniemieckim jadem” i „w istocie skierowane było przeciw Niemcom” ${ }_{52}$ - mimo że mówca jednocześnie mocno akcentował solidarność Włoch z Rzesza. W swym wystapieniu Ciano przypominał m.in. mediolańskie rozmowy włosko-niemieckie z 6 i 7 maja, w trakcie których stwierdzono, że konieczne będzie zachowanie pokoju przez trzy (tak oceniali włoscy uczestnicy rozmów) lub nawet cztery do pięciu lat (tak Niemcy). Gdy jednak w swej kolejnej rozmowie na ten temat $\mathrm{z}$ Weizsäckerem włoski chargé d'affaires (ambasador Attolico przebywał w Rzymie) utrzymywał, jakoby przemówienie miało charakter proniemiecki, sekretarz stanu był zupełnie innego zdania, zwracając radcy ambasady Włoch (i szwagrowi Ciana) Massimowi Magistratiemu uwagę na dość zgodne w tej kwestii komentarze prasy zagranicznej ${ }^{53}$. Attolico po powrocie do Berlina otwarcie zapytał Weizsäckera, o co Niemcy maja pretensje i uzyskał podobną odpowiedź. Ambasador tłumaczył swego przełożonego względami wewnętrznymi i rzekomą koniecznością wyjaśnienia włoskiej opinii publicznej, dlaczego Italia nie weszła do wojny u boku swego niemieckiego sojusznika ${ }^{54}$. Do mowy Ciana osobiście wrócił sam Ribbentrop w rozmowie z Attolicem 28 grudnia, lecz w niemieckiej notatce sporządzonej z tego spotkania zwraca uwagę co innego. Ribbentrop otóż wyraził zdziwienie z powodu „antyrosyjskiej postawy Italii”, ponieważ jego zdaniem ani Niemcom, ani Włochom nic nie grozi ze strony ZSRR ${ }^{55}$.

Ostrzeżenia przed zaborczością Kremla i zagrożeniem ze strony komunizmu płynęły z Włoch $\mathrm{w}$ następnych miesiącach. I tak radca ambasady niemieckiej zanotował w styczniu 1940 r. słowa gen. Maria Roatty, że „dla Europy jedynym rzeczywistym niebezpieczeństwem jest bolszewizm”. Włoski generał, zastępca szefa Sztabu Generalnego, oznajmiał, iż „nadejdzie czas, gdy inne kraje porozumieją się, by wspólnie podjać walkę z Rosja”, a rozbicie ZSRR byłoby jego zdaniem - jak wskazywał kompromitujący Armię Czerwona przebieg wojny z Finlandia - „drobnostką”. Roatta zresztą uważał, że rozległe terytoria Rosji dałyby dostatecznie dużo „przestrzeni życiowej” dla wszystkich państw zainteresowanych walką z imperium Stalina. W każdym razie byłoby dobrze, ciagną włoski wojskowy, gdyby Niemcy wyraźnie zasygnalizowały, że nie łączą je ze Związkiem Radzieckim jakiekolwiek więzi sojusznicze. Zresztą i Brytyjczycy powinni zdaniem Roatty zrozumieć, że ich głównym wrogiem wcale nie jest Rzesza, prawdziwe zagrożenie stanowi bowiem ZSRR ${ }^{56}$.

52 Ibidem, s. 453 (16 XII 1939). Ciano dodawał, że przemówienia gratulował mu ambasador Wielkiej Brytanii, sir Percy Loraine. Obszerne streszczenie mowy Ciana w: F. Siebert, op. cit., s. 386-388, przypis 5.

${ }^{53}$ ADAP, D, VIII, dok. 478.

${ }^{54}$ PAAA Berlin, Büro Staatssekretär, Italien, 2, f. 487, notatka Weizsäckera z 23 XII 1939.

${ }^{55}$ ADAP, D, VIII, dok. 493.

${ }^{56}$ PAAA Berlin, Botschaft Rom (Quirinal) geheim, t. 70, notatka radcy von Plessena z 11 I 1940 (rozmowa miała miejsce dzień wcześniej). 
Przemówienie włoskiego ministra stało się w końcu jednym z wątków listu Mussoliniego do Hitlera z początku stycznia 1940 r. Listem tym kanclerz powracał do przerwanej korespondencji z włoskim dyktatorem. Duce podkreślał, że całkowicie utożsamia się z wywodami swego zięcia, „od początku jednego z najbardziej zagorzałych orędowników przyjaźni włosko-niemieckiej”, a wszelkie zarzuty wobec Ciana określał jako „śmieszne”. Niemniej odradzał Hitlerowi atak na Francję i zalecał nawiązanie rokowań pokojowych. Opowiadał się też za odtworzeniem jakiejś formy państwa polskiego. Wśród wielu wątków pisma Mussoliniego znalazła się również sprawa Finlandii. Duce pisał o przyjaznym nastawieniu faszystowskiej Italii do „tego małego, dzielnego narodu". Zaznaczał, że Rzym chciałby dostarczyć Helsinkom 25 samolotów zamówionych jeszcze przed wybuchem wojny zimowych i pisał, że we Włoszech zgłosiły się tysiące ochotników chcących wyjechać na front fińsko-radziecki. Co więcej, Mussolini przestrzegał Hitlera przed dalszym zacieśnianiem stosunków z ZSRR, wskazując, że w antykomunistycznie nastawionym społeczeństwie włoskim zostałoby to przyjęte jak najgorzej (pisał o „katastrofalnych” wręcz konsekwencjach). Zaznaczał przy tym, że rozwiązanie problemu niemieckiego Lebensraum stanowi właśnie obszar Związu Radzieckiego. Dodawał, iż jeszcze cztery miesiące wcześniej ZSRR był dla Berlina „światowym wrogiem numer jeden”, podczas gdy teraz staje się „przyjacielem numer jeden”. „Głęboko poruszyło to faszystów we Włoszech i zapewne również wielu narodowych socjalistów w Niemczech”. Pisał w końcu, że „dzień, w którym zniszczymy bolszewizm”, będzie oznaczał dopełnienie „obu naszych rewolucji”. A „później przyjdzie pora na wielkie demokracje, które nie przeżyją toczącego je raka”. Niemniej zapewniał Mussolini Hitlera, że Rzym przygotowuje się do włączenia się do wojny, lecz moment ten musi być wybrany starannie, gdyż Włochy nie moga i nie chca brać udziału w długotrwałej wojnie ${ }^{57}$.

Jak się wkrótce miało okazać, list wodza włoskiego faszyzmu został w Berlinie przyjęty źle, choć nie dotyczyło to wszystkich niemieckich prominentów ${ }^{58}$. Weizsäcker po wojnie pisał w swych wspomnieniach, że „za listem stał naturalnie Attolico" ${ }^{59}$. Niechęć tego ostatniego do udziału Włoch w wojnie nie była dla strony niemieckiej żadna tajemnica, Dyplomata ten został zresztą niedługo później, ku dużej satysfakcji gospodarzy, odwołany z Berlina, o czym jeszcze napiszę.

\footnotetext{
${ }^{57}$ ADAP, D, VIII, dok. 504; data listu niepewna, 3 lub (bardziej prawdopodobne) 5 I 1940; por. G. Ciano, op. cit., s. 463-464 (3 i 5 I 1940). O roli prób mediacji we włoskiej polityce zagranicznej tego okresu zob. H. Cliadakis, Neutrality and War in Italian Policy 1939-40, „Journal of Contemporary History” 1974, nr 9, s. 171; U. Schlie, Kein Frieden mit Deutschland. Die geheimen Gespräche im Zweiten Weltkrieg 1939-1941, München-Berlin 1994, s. 76-82 (z charakterystycznym tytułem podrozdzialu: „Nieproszone rady”).

${ }^{58} \mathrm{Na}$ przykład adm. Wilhelm Canaris w rozmowie z włoskim attaché wojskowym wyrażał się o liście bardzo pozytywnie. DDI, II, dok. 205.

${ }^{59}$ E. von Weizsäcker, op. cit., s. 274.
} 
Niemieckie oceny dotyczące nastawienia Włoch wobec Rzeszy były dość trzeźwe. W konkluzji analizy wysłanej przez ambasadę w Rzymie 3 I 1940 r. stwierdzano, że polityka zbliżenia z Berlinem jest w społeczeństwie włoskim mało popularna, a jedynym w zasadzie rzecznikiem włoskiej polityki w duchu Osi okazał się sam Mussolini - osobiście jak najbardziej lojalny wobec Niemiec, lecz ograniczany poprzez nieprzygotowanie jego kraju do wejścia do wojny (hr. Ciana do przyjaciół Niemiec autor analizy nie zaliczał). W dokumencie zauważano jednak, że w niemiecko-włoskich rozmowach sprzed kilku miesięcy ustalono, iż wojny można się spodziewać dopiero za kilka lat, co powinno tłumaczyć obecną niechęć Rzymu do udziału w wojnie. Na wiosnę jednak, zdaniem autora, Duce chciałby mieć szansę podjęcia, rzecz jasna w miarę możliwości, również i takiej decyzji ${ }^{60}$.

W rozmowie z ambasadorem Attolicem 10 stycznia Ribbentrop był już bardziej szorstki. Nie ukrywał, że ma poważne zastrzeżenia do wspomnianego przemówienia Ciana, które jego zdaniem przedstawiało Niemcy jako mocarstwo prące do wojny i ponoszące winę za jej wybuch. Przede wszystkim jednak szef AA krytykował antyradzieckie i antykomunistyczne fragmenty listu Mussoliniego do Hitlera i zwracał uwagę, że przecież wcześniej obaj dyktatorzy zgodzili się, że zagrożenie dla reżimów faszystowskiego i narodowosocjalistycznego stanowia przede wszystkim Francja i Wielka Brytania. Nie rozumiał - jak mówił - wrogości Włoch wobec ZSRR, państwa, które przecież nie zagrażało ani Niemcom, ani Italii. Utrzymywał nawet, jakoby winę za wybuch wojny zimowej ponosił Londyn, który wmanewrował Helsinki w konflikt z Moskwa, a Stalin wojny z Finlandią nie chciał. „Nie wierzę zresztą w rosyjską politykę ekspansji, lecz myślę, że chodzi raczej o ograniczony rewizjonizm, wymierzony w narzucone Rosji powojenne traktaty" - mówił szef hitlerowskiej dyplomacji. Nawiązując zaś do oczekiwań Mussoliniego w sprawie możliwości zawarcia przez Berlin pokoju z zachodnimi mocarstwami, Ribbentrop podkreślił, że nie ulega wattpliwości, iż „postawa Anglii dowodzi woli zniszczenia, rozczłonkowania i wytępienia narodu niemieckiego" ${ }^{61}$. Ribbentropowi zależało (mówił o tym przy innej okazji) na przekonaniu Włochów, że współpraca z ZSRR nie ma nic wspólnego z przyjaźnią, opiera się na trzeźwych, realistycznych kalkulacjach i nie niesie ze sobą ryzyka „bolszewizacji Europy”, gdyż Zwiazek Radziecki przez najbliższych 10-15 lat w ogóle nie będzie „zdolny do działania" (aktionsfähig) ${ }^{62}$.

Niemcy mieli też pretensje do swych włoskich partnerów, że ci w ramach kontaktów handlowych dostarczają Francji materiały wojenne (chodziło m.in. o sprzedaż silników lotniczych). Z Rzymu odpowiadano, że Italia bez tego rodzaju eksportu bardzo szybko zostałaby bez dewiz, a zatem również bez

\footnotetext{
${ }^{60}$ ADAP, D, VIII, dok. 505. Autorem analizy był radca Johann von Plessen.

${ }^{61}$ Ibidem, dok. 518. Raport Attolico: DDI, nona serie, t. III, dok. 78.

${ }^{62}$ ADAP, D, VIII, dok. 596.
} 
surowców koniecznych do przygotowań wojennych. Berlinowi trudno było to zakwestionować, niemniej strona niemiecka życzyła sobie, by Rzym w jak najmniejszym stopniu przyczyniał się do zwiększania potencjału wojskowego Francji oraz Wielkiej Brytanii, jednocześnie zwiększając do granic możliwości dostawy dla niemieckiego sojusznika. Apelowano też o to, by Italia stawiała jak największy opór brytyjskim zarządzeniom w zakresie blokady morskiej ${ }^{63}$. Odniosło to w końcu skutki, gdyż przeżywający huśtawkę nastrojów Mussolini $\mathrm{w}$ kolejnym przypływie germanofilstwa wydał w lutym zarządzenia znaczaco ograniczające wymianę handlowa z Wielką Brytanią. Zbiegło się to z wizyta w Rzymie specjalnego wysłannika Hitlera, jakim był ksiąze Filip Heski. Arystokratę tego, zięcia króla Wiktora Emanuela III, Führer już wcześniej wykorzystywał do różnych misji i rozmów z Duce.

Przyjęty przez Mussoliniego książę von Hessen przedstawił propozycję Hitlera, by obaj dyktatorzy spotkali się na granicy, na co Duce zgodził się natychmiast. Wyraźnie podekscytowany, wyrażał się w mocno wojowniczym stylu. Wysłannik kanclerza usłyszał zatem, że Mussolini - jak streszczał wypowiedź Ciano - „zamierza stanąć u boku Niemiec, gdy tylko nasze zbrojenia pozwola, abyśmy byli dla Niemców pomoca, a nie ciężarem" ${ }^{4}$.

Poważne znaczenie dla zacieśnienia stosunków dwustronnych miało podpisanie w Rzymie 24 lutego układu gospodarczego, wieńczącego trudne negocjacje prowadzone $\mathrm{w}$ stolicy Włoch przez niemiecką delegację rządowa z Karlem Clodiusem z Auswärtiges Amt na czele. Był to tzw. czwarty tajny protokół; poprzednie podpisano 14 V 1937 r., 18 XII 1937 r. i 13 II 1939 r. $\mathrm{Na}$ mocy najnowszego z nich m.in. Włochy miały otrzymywać z Niemiec 500 tys. ton węgla miesięcznie z zastrzeżeniem, że włoskie koleje podstawią ok. 5 tys. wagonów węglarek ${ }^{65}$. Jednocześnie Mussolini zobowiązywał się dostarczyć Rzeszy inne potrzebne jej surowce. Wkrótce jednak Wielka Brytania ostrzegła Rzym, że nie pozwoli na dostarczanie do Włoch niemieckiego węgla drogą morska, z portów w Rotterdamie ${ }^{66}$. Obciążyło to poważnie stosunki włosko-brytyjskie.

Hitler kazał Mussoliniemu długo czekać na odpowiedź na list z początku stycznia; zwracał na to uwagę Attolico podczas wizyty na Wilhelmstrasse

${ }^{63}$ G. Ciano, op. cit., s. 467 (14 I 1940); ADAP, t. VIII, np. dok. 593.

${ }^{64}$ G. Ciano, op. cit., s. 476 (8 II 1940). Podobny zapis na podstawie relacji księcia Filipa Heskiego w: F. Halder, Dziennik wojenny, t. I, Warszawa 1971, s. 255 (12 II 1940): „Książę Hesji: Duce chce przystapić do działań, jeśli tylko będzie to pomoca, a nie obciązeniem dla Niemiec". W archiwach niemieckich nie odnaleziono materiałów związanych z tą wizyta księcia Heskiego.

${ }^{65}$ Tekst niemiecki: ADAP, t. VIII, dok. 634. O negocjacjach: ibidem, dok. 623, 627. Tajny protokół dodatkowy do tego porozumienia został podpisany 13 marca. Ustalono w nim, że niemieckie dostawy węgla będą osiagać miesięcznie $1 \mathrm{mln}$ ton. DDI, III, App. II, 2, s. 642, do tego dok. 513, 514 .

${ }^{66}$ ADAP, D, VIII, dok. 647, 652. 
29 stycznia ${ }^{67}$. Sam kanclerz 2 lutego w rozmowie z pytającym o to, kończącym swą misję w Berlinie, radcą Magistratim nie wysilił się na jakiekolwiek przekonujące wyjaśnienie powodu tej zwłoki ${ }^{68}$. Był to wyraźny afront, lecz Duce zdawał się nie przyjmować tego do wiadomości. W końcu odpowiedź Hitlera, datowana 8 marca, została przekazana Mussoliniemu przez Ribbentropa 10 marca z okazji dość dla Włochów nieoczekiwanej wizyty ${ }^{69}$ niemieckiego ministra w Rzymie. Ribbentrop wyjaśniał Mussoliniemu, że Führer tak długo zwlekał z odpowiedzia, ponieważ chciał najpierw wyrobić sobie „jasny obraz” sytuacji. Obszerny list kanclerza poruszał wiele wątków, ale $\mathrm{w}$ gruncie rzeczy nie zawierał niczego istotnego. Znalazła się w nim jednak osobliwa ocena ustroju ZSRR, Hitler bowiem usiłował przekonać swego partnera, jakoby w Związku Radzieckim system bolszewicki przekształcił się już $\mathrm{w}$ formę systemu nacjonalistycznego, którego fundamentem stała się „rosyjsko-narodowa idea państwowa”70. Większe znaczenie niż te wywody miały z włoskiego punktu widzenia złożone w imieniu Hitlera zapewnienia Ribbentropa, iż Rzesza w całości gotowa jest pokryć włoskie zapotrzebowanie na węgiel. Jeszcze bardziej istotna okazała się deklaracja Mussoliniego w rozmowie z Ribbentropem 11 marca, iż Italia w stosownym dla niej terminie włączy się do wojny i „będzie toczyć paralelną wojnę wobec tej, którą prowadzą Niemcy, a zatem - w praktyce - przyłączy się do nich"71. W telegramie nadanym w drodze powrotnej późnym wieczorem 12 marca ze swego pociagu specjalnego Ribbentrop streszczał Hitlerowi słowa Duce, zapewniającego o istnieniu „wspólnoty losu” Niemiec i Włoch: „Italia stoi bezwzględnie po stronie Niemiec. Watpienie w to obraża Włochy. Duce oświadczył, że Włochy przystapia do wojny u boku Niemiec, a jeśli będzie potrzeba, przystapienie takie sprowokuje" 72 .

Ribbentrop w imieniu kanclerza zaprosił Mussoliniego na bezpośrednią rozmowę z Hitlerem na granicznej przełęczy Brenner. Wódz włoskiego faszyzmu zgodził się natychmiast. Ciano jednak nieco lękał się tej rozmowy: „Duce ulega fascynacji Hitlerem, tym bardziej że oddziałuje ona na to, co najgłębiej tkwi w jego naturze - na pragnienie działania. Führer wydrze od Duce znacznie więcej, niżby uzyskał Ribbentrop"73.

Wielogodzinne spotkanie obu dyktatorów na zaśnieżonym Brennerze miało miejsce 18 marca. Rozmowę zdominował kanclerz. Rok później Hitler mówił, że Mussolini w trakcie spotkania sprawiał wrażenie zakłopotanego

67 Ibidem, dok. 583.

68 Ibidem, dok. 591.

${ }^{69}$ Mackensen zawiadomił o niej Ciana ledwie dwa dni wcześniej.

${ }^{70}$ ADAP, D, VIII, dok. 663.

${ }^{71}$ G. Ciano, op. cit., s. 489 (11 III 1940); o rozmowach z Ribbentropem s. 488-489 (10 i 11 III 1940). Do tego: ADAP, D, VIII, dok. 665, 666, 667, 669, 670.

72 ADAP, D, VIII, dok. 670.

${ }^{73}$ G. Ciano, op. cit., s. 489 (12 III 1940). 
niczym uczeń, który nie odrobił porządnie zadania domowego ${ }^{74}$. Wódz włoskiego faszyzmu był, jak pisze jeden z jego licznych biografów, „jak zwykle zahipnotyzowany, oczarowany pewnością siebie Hitlera i jednocześnie miał poczucie winy, iż Włochy nie przystapiły do wojny"75. Kanclerz rozwlekle przedstawiał swoje argumenty, oceny i kalkulacje. Przykładowo w sprawach rosyjskich stwierdzał, że okoliczności zmusiły go do zawarcia porozumienia ze Stalinem. Twierdził, że w ZSRR dokonuje się transformacja ustroju bolszewickiego w państwo zdominowane przez nacjonalistyczna ideologię słowiańsko-moskiewską. Mówił, że jest zdecydowany pielęgnować przyjazne stosunki z ZSRR, zwłaszcza że na płaszczyźnie ekonomicznej oba mocarstwa uzupełniają się. Generalnie jednak, ciagnął Hitler, „Niemcy maja jednego tylko sojusznika i przyjaciela: Italię". Natomiast niczym groźba zabrzmiała aluzyjna uwaga Hitlera, że „jeśli Włochy chcą zadowolić się drugorzędną rolą na Morzu Śródziemnym, wówczas nic nie muszą robić, ale jeśli chcą być tam czołowym mocarstwem, to muszą liczyć się z przeciwdziałaniem zachodnich mocarstw"76.

Führer nie nalegał, by Duce określił datę wejścia Italii do wojny. Mówił tylko, że włoska interwencja powinna nastapić wtedy, gdy uderzenie to przyczyni się do zwycięstwa w sposób decydujący. Mussolini z kolei wyrażał jedynie watpliwości, czy Niemcy powinny ryzykować frontalne uderzenie na zachodzie i sugerował zawarcie kompromisowego pokoju. Oznajmił, że w ciagu 3-4 miesięcy Włochy będa gotowe do militarnej interwencji po stronie Rzeszy. Dodał jednak, że ze względów finansowych Italia na dłuższą wojnę pozwolić sobie nie może. Jeśli ofensywa niemiecka będzie rozwijała się pomyślnie, Włochy wystapią szybko, by przyspieszyć klęskę nieprzyjaciela. Generalnie marcowe spotkanie na Brennerze stanowiło odnowienie i niewatpliwe wzmocnienie sojuszu obu państw Osi. Hitler mógł być w końcu przekonany, że włoska non belligeranza zbyt długo nie potrwa. Z Brenneru wrócił do Niemiec, jak odnotował to w swych zapiskach gen. Alfred Jodl, rozpromieniony ${ }^{77}$. W samych superlatywach wyrażał się o Mussolinim także w rozmowie z Goebbelsem. „Mamy w nim szczerego i prawdziwego przyjaciela” - notował minister propagandy w prywatnym dzienniku. Uważano jednak, że otoczenie Duce mu nie dorównuje, a „dom królewski bardzo mu przeszkadza”78.

Wkrótce Mussolini zasiadł do pracy nad memorandum, które 31 marca przedłożył Wiktorowi Emanuelowi III, a kilka dni później także swemu zięciowi oraz najwyższym dowódcom włoskich sił zbrojnych. W piśmie tym podkreślał, że jeśli Italia chce być mocarstwem, nie może dłużej pozostawać z daleka

${ }^{74}$ E. von Rintelen, Mussolini als Bundesgenosse. Erinnerungen des deutschen Militärattachés in Rom 1936-43, Tübingen-Stuttgart 1951, s. 81.

${ }^{75}$ D. Mack Smith, Mussolini, Warszawa 1994, s. 314.

${ }^{76}$ ADAP, D, IX, dok. 1.

${ }^{77}$ Der Prozeß gegen die Hauptkriegsverbrecher vor dem Internationalen Militärgerichtshof, Nürnberg, 14. November 1945 - 1. Oktober 1946, t. XXVIII, Nürnberg 1948, s. 414.

78 J. Goebbels, op. cit., t. II, s. 57 (20 III 1940). 
od trwającej wojny europejskiej, a sprawą do rozważenia jest tylko wybór konkretnej daty. Celem wojennym Rzymu miały być: dominacja w basenie Morza Śródziemnego, uzyskanie Korsyki, Malty i Tunezji, a także usunięcie Brytyjczyków zarówno z Egiptu (Kanał Sueski), jak i z Gibraltaru. Chyba wszystkie osobistości, jakie otrzymały memoriał (Ciano odnotował w swym dzienniku, że dokument został sporządzony w ośmiu kopiach), były przeciwne udziałowi w wojnie, lecz żadna $\mathrm{z}$ nich nie zdecydowała się na wyrażenie zdecydowanego sprzeciwu i przeciwstawienie się dyktatorowi, od dłuższego już czasu z tygodnia na tydzień coraz bardziej proniemieckiemu.

Niemcy o tym nie wiedzieli, ale zdawali sobie sprawę z apetytów Mussoliniego. I tak 24 kwietnia Mackensen depeszował o uzyskanej od jednego z zaufanych informatorów treści poufnego wystapienia Mussoliniego do działaczy organizacji syndykalistycznych i korporacyjnych. Duce wówczas mocno podkreślał, że zaryglowane w basenie Morza Śródziemnego z trzech stron (Gibraltar, Suez, Dardanele) Włochy nie mają dostępu do oceanu. Kiedyś, gdy Italia była słaba, nie miało to znaczenia, jednak w obliczu wzrostu potęgi włoskiej sytuacja zmieniła się. Mussolini podkreślał, że te ograniczające Włochy „kraty tkwią w naszym ciele i sprawiają nam ból”79.

Upokarzające dla Włoch było powstrzymywanie się niemieckiego sojusznika z bliższymi informacjami, kiedy mniej więcej można by liczyć się z uderzeniem na Francję. Pytany 1 kwietnia przez Ciana o termin ofensywy niemieckiej na Zachodzie ambasador Mackensen odpowiadał zgodnie z prawda, że wiadomościami na ten temat nie dysponuje. Włoski minister (kolejny już zreszta raz) zaznaczył, że Rzymowi bardzo na tej informacji zależy ze względu na konieczność odpowiednio wczesnego przygotowania się do nowej sytuacji ${ }^{80}$.

Berlin nie uprzedził swego włoskiego sojusznika o przygotowywanym ataku na Danię i Norwegię. Instrukcja Ribbentropa w tej sprawie wyszła już 7 kwietnia, ale ambasador Rzeszy miał zawiadomić o tym Włochów dopiero rankiem 9 kwietnia, gdy niemieckie operacje były już w toku. Wtedy też Mackensen przekazał nowy list Hitlera, adresowany do Mussoliniego. Chcac nie chcąc Duce, przyjmując niemieckiego ambasadora, czuł się zmuszony wyrazić „całkowita akceptację” decyzji Führera ${ }^{81}$. Tymczasem jeszcze w przeddzień niemieckiego ataku kierownik Wydziału Politycznego AA Ernst Woermann na pytanie radcy ambasady Włoch Guelfa Zamboniego, ile jest prawdy w pogłoskach o niemieckim uderzeniu na Norwegię, odpowiadał, że to nonsens. Osobliwie w świetle tego, co miało stać się następnego dnia, brzmiała prośba włoskiego dyplomaty, by Auswärtiges Amt na bieżąco informował ambasadę Italii o zamierzeniach Berlina w sprawie Norwegii ${ }^{82}$.

\footnotetext{
${ }^{79}$ PAAA Berlin, Botschaft Rom (Quirinal) geheim, t. 74, Mackensen do AA, 24 IV 1940.

${ }^{80}$ PAAA Berlin, Nachlass von Mackensen, t. 4 (1940), Mackensen do AA, 1 IV 1940.

${ }^{81}$ ADAP, D, VIII, dok. 56; list Hitlera do Mussoliniego: ibidem, dok. 68 (tłumaczenie włoskie, oryginał niemiecki nie zachował się). Rozmowa Mussolini-Mackensen: ibidem, dok. 69 .

${ }^{82}$ ADAP, D, IX, dok. 64.
} 
Cieszyć też musiała Niemców zimna, a nawet niegrzeczna odpowiedź Mussoliniego na list Paula Reynauda z 22 kwietnia, w którym nowy premier Francji apelował o przywrócenie dobrych ongiś stosunków między obydwoma krajami i proponował bezpośrednie spotkanie. W odpowiedzi tej szef rządu włoskiego podkreślał, że Italia jest od maja 1939 r. sojusznikiem Rzeszy, z czego należy wyciagać daleko idące wnioski; Ciano zanotował, że list był „oziębły, zgryźliwy i pogardliwy” ${ }^{3}$. W tych też dniach rozstrzygnęła się sprawa zmiany na stanowisku ambasadora w Berlinie. Mussolini i Ciano wyszli naprzeciw sugestiom niemieckim ${ }^{84}$, by odwołać wyraźnie sceptycznego wobec zacieśniania sojuszu z Niemcami Bernarda Attolica. Został on skierowany do Watykanu, o co zadbał Ciano, uważajacc, że Attolico jednak „bardzo dobrze wypełniał swoja misję"85. Miejsce Attolica w stolicy Rzeszy obją Dino Alfieri, wcześniej minister prasy i propagandy, następnie szef resortu kultury ludowej, a od 1939 r. ambasador przy Stolicy Apostolskiej, a więc tam właśnie, dokąd teraz odchodził Attolico ${ }^{86}$. Zmiana ta została w Berlinie przyjęta z dużą satysfakcja. „Wszyscy jesteśmy zadowoleni, że teraz przychodzi Alfieri” - notował Goebbels wkrótce po tym, jak dosadnie skomentował postawę dotychczasowego ambasadora Italii: „Nie jest on [Attolico - S.Ż.] faszysta, lecz tchórzem. Faszyzm to znaczy gardzić niebezpieczeństwem i wygodnictwem. W przypadku Attolico nie może być o tym mowy" ${ }^{87}$. W drugiej połowie kwietnia krążyły zresztą w Rzymie także plotki, jakoby Mussolini zamierzał zdymisjonować samego Ciana. Źródłem tych spekulacji była przedłużająca się, wielodniowa nieobecność ministra złożonego grypa, interpretowana dość powszechnie jako „choroba dyplomatyczna”, zwiastująca jakoby odwołanie sceptycznego wobec zacieśniania związków z Rzeszą zięcia włoskiego dyktatora ${ }^{88}$.

Niemieckie zbrojne uderzenia na Zachodzie zmuszały Mussoliniego do zweryfikowania włoskich planów ekspansji kierowanej w stronę Bałkanów. Duce od pewnego czasu nosił się z zamiarem zaatakowania Jugosławii. Był też przekonany o konieczności przeciwdziałania na wypadek, gdyby Związek Radziecki próbował usadowić się także w tym rejonie. 18 kwietnia Attolico mówił sekretarzowi stanu w AA Weizsäckerowi o włoskich obawach związanych z możliwym wtargnięciem ZSRR na Bałkany. Zastępca Ribbentropa cytował uspokajajace meldunki ambasadora Friedricha Wernera von der Schulenburga z Moskwy, ale Włoch prosił usilnie o jak najszybsze udzielenie informacji,

${ }^{83}$ G. Ciano, op. cit., s. 508 (26 IV 1940); ADAP, D, VIII, dok. 173.

${ }^{84}$ Niedwuznaczne aluzje na ten temat padły np. podczas rozmowy ambasadora Niemiec w Rzymie z Mussolinim 25 kwietnia. ADAP, D, IX, dok. 165.

${ }^{85}$ „Nie chcę, aby Niemcy odnieśli wrażenie, że wystarczy ich jeden «kciuk w dół», żeby wykończyć naszego człowieka, który bardzo dobrze wypełniał swoja misję". G. Ciano, op. cit., s. 509 (26 IV 1940).

${ }^{86}$ Ibidem, s. 507, 508 (24 i 25 IV 1940); ADAP, D, VIII, dok. 181.

87 J. Goebbels, op. cit., t. II, s. 66 (2 V 1940).

${ }^{88}$ G. Ciano, op. cit., s. 505 (20 IV 1940); zob. też raport w sprawie plotek na temat różnic zdań między Mussolinim a Ciano: ADAP, VIII, dok. 170. 
gdyby sytuacja na tym odcinku stać się miała napięta, gdyż „Bałkany obchodzą przecież Italię bardziej niż Skandynawia" ${ }^{9}$. Tymczasem niemieckie sukcesy w Skandynawii i perspektywa ofensywy przeciwko Francji zmuszały Duce do porzucenia bałkańskich ambicji i skierowania wzroku ku Francji.

Wkrótce zresztą włoski dyktator otrzymał kolejny list (z datą 10 kwietnia), w którym Hitler informował swego partnera o dotychczasowym przebiegu operacji wojskowych. Reakcja Mussoliniego była entuzjastyczna, a działania niemieckie określił mianem „mistrzowskiego uderzenia”90. Już 11 kwietnia odpisał Hitlerowi, że jakkolwiek włoska opinia publiczna chciałaby pewnej zwłoki w celu dozbrojenia kraju, to jednak Włosi zrozumieli, że Italia nie może dłużej pozostawać poza konfliktem. Dodawał, że włoska marynarka wojenna jest gotowa do wojny ${ }^{91}$. W następnych dniach (18 i 26 kwietnia oraz 3 maja) Mussolini otrzymywał od Führera kolejne listy informujące o postępach niemieckich sił zbrojnych. Ciano uważał, że Hitler był „dobrym psychologiem” i wiedział, że „te jego pisma działają bardzo porywająco na duszę Mussoliniego" ${ }^{2}$. Niemcy byli coraz bardziej usatysfakcjonowani. Goebbels notował na początku maja: „Włochy staja dzielnie po naszej stronie. Prasa rzymska pisze prawie tak samo jak berlińska" ${ }^{93}$.

Niemniej termin wielkiej niemieckiej ofensywy, która ruszyła na froncie zachodnim (10 maja), Berlin do ostatniej chwili zatajał przed włoskim sojusznikiem. Powtórzyła się sytuacja sprzed miesiąca. Już 7 maja ambasador Mackensen został poinformowany, że w dniu, o którego dacie zawiadomi go ustnie specjalny kurier, ma wczesnym rankiem pojawić się u Mussoliniego, wręczając mu dwa memoranda o niemieckiej operacji. Nad ranem 10 maja ambasador Rzeszy zadzwonił do Ciana, by ten go natychmiast przyją, a następnie obaj przybyli do Duce. Wręczone Mussoliniemu pismo od Hitlera kończyło się propozycja, by Duce - tak zanotował Ciano - „podją decyzje, jakie uzna za konieczne dla przyszłości swojego narodu” ${ }^{4}$. W tym samym czasie oddziały niemieckie ruszały na froncie zachodnim do ofensywy.

„Duce zareagował bardzo entuzjastycznie na wiadomość o natarciu” w swym dzienniku wojennym szef Sztabu Generalnego wojsk lądowych gen. Franz Halder odnotował słowa, jakie padły 10 maja na wieczornej konferencji u Hitlera ${ }^{95}$. Wkrótce, pod wrażeniem militarnych sukcesów

${ }^{89}$ PAAA Berlin, Büro Staatssekretär, Diplomatenbesuche, t. 6, f. 1537, notatka Weizsäckera z 18 IV 1940.

90 ADAP, D, VIII, dok. 86 (list Hitlera: ibidem, dok. 82).

${ }^{91}$ Ibidem, dok. 138.

${ }_{92}$ G. Ciano, op. cit., s. 509 (28 IV 1940), reakcja na list Hitlera z 26 kwietnia.

${ }^{93}$ J. Goebbels, op. cit., t. II, s. 65 (2 I 1940).

${ }^{94}$ G. Ciano, op. cit., s. 514-515 (10 V 1940). Datowany 9 maja list Hitlera: ADAP, t. VIII, dok. 212 (jedynie włoskie tłumaczenie, niemiecki oryginał nie został odnaleziony).

${ }^{95}$ F. Halder, op. cit., t. I, s. 370 (10 V 1940). 
swego sojusznika, wiara Mussoliniego w zwycięstwo Rzeszy wzrosła jeszcze bardziej. W rozmowie $\mathrm{z}$ ambasadorem Mackensenem 14 maja po raz pierwszy oznajmił, że Włochy niedługo wejdą do wojny, dodając, że stanie się to w ciagu najbliższych 10-14 dni. Zaznaczył, że o ile włoskie siły lądowe może nie będą czynnikiem o dużej wadze, to już w przypadku marynarki wojennej i lotnictwa Italia wniesie poważny wkład do wspólnego zwycięstwa ${ }^{96}$. Kolejne listy Hitlera, relacjonujące postępy sił niemieckich, jeszcze bardziej umacniały Mussoliniego w przekonaniu, że Włochy powinny porzucić dotychczasowa postawę. Świeżo mianowany włoski ambasador w Berlinie Alfieri 19 maja wyraźnie już zapowiadał na Wilhelmstrasse, iż Rzym wkrótce znajdzie się w wojnie ${ }^{97} .10$ dni później już nawet Ciano zapewniał Mackensena, że Italia wystapi tak szybko, jak to możliwe, i drwił z zastrzeżeń włoskich wojskowych, „którzy nigdy nie będą gotowi” ${ }^{98}$. Dla niemieckiego ambasadora nie było to nic nowego, ponieważ już 26 maja usłyszał od samego Mussoliniego, że ten nie może dłużej czekać i „uderzy za kilka dni” ${ }^{9}$. Zresztą Niemcy dysponowali tłumaczeniami odpowiedzi Duce na listy Winstona Churchilla i Franklina D. Roosevelta. I tak 18 maja w odpowiedzi na list prezydenta Stanów Zjednoczonych wódz włoskiego faszyzmu pisał niedwuznacznie: „Pańskiemu realnemu duchowi politycznemu nie mogą ujść uwagi dwa podstawowe elementy aktualnej sytuacji politycznej włoskiej, a mianowicie, że Włochy zamierzaja pozostać sprzymierzone z Niemcami i że Włochy nie moga stać na uboczu w momencie, kiedy ważą się losy przyszłości Europy" 100.

Z kolei 25 maja ambasador Rzeszy depeszował do Berlina, że w Rzymie na murach pojawiły się plakaty z napisem „Evviva la Korsika Italiana”. Mackensen dowiadywał się z dobrze poinformowanego źródła, że zarządził to osobiście Duce. Poprzedniego dnia zorganizowano też na Piazza del Popolo manifestację na cześć osiemnastowiecznego korsykańskiego irredentysty Pasquale Paoliego ${ }^{101}$. A 30 maja Mussolini wysłał list do Hitlera z wiadomością, że Włochy będą gotowe do udziału w wojnie 5 czerwca, ale na życzenie kanclerza mógłby jeszcze kilka dni zaczekać. Hitler jednak decyzję w tej kwestii pozostawiał Mussoliniemu ${ }^{102}$. W końcu ambasador niemiecki w Rzymie Mackensen mógł 2 czerwca poinformować Berlin, że Włochy wypowiedza wojnę Francji i Wielkiej Brytanii 10 czerwca, przy czym działania wojenne rozpocząć się miały następnego dnia ${ }^{103}$. Brytyjczycy i Francuzi również byli tego świadomi. W rzymskich ambasadach obu zachodnich mocarstw niszczono

\footnotetext{
${ }^{96}$ ADAP, D, VIII, dok. 242.

${ }^{97}$ Ibidem, dok. 275.

${ }^{98}$ Ibidem, dok. 343.

99 PAAA Berlin, Büro Staatssekretär, Italien, 3, f. 493, Mackensen do AA, 26 V 1940.

100 F. Halder, op. cit., t. II, s. 400 (załącznik do zapisów z 22 V 1940).

101 PAAA, Berlin, Büro Staatssekretär, Italien 3, f. 493, Mackensen do AA, 25 V 1940.

102 ADAP, D, VIII, dok. 356, 370. Do tego zapisy w Dzienniku Ciana.

103 Ibidem, dok. 372.
} 
lub pakowano dokumenty, a włoskie MSZ przygotowywało transporty, by umożliwić wyjazd personelowi obu misji ${ }^{104}$.

Włoskie dowództwo chcąc nie chcąc zaaprobowało decyzję o wejściu Italii do wojny ${ }^{105}$. Strona niemiecka zdawała sobie sprawę i z zastrzeżeń włoskich wojskowych, i z nieprzygotowania Italii. Ambasador Mackensen informował Ribbentropa 30 maja, że niemal na wszystkich odcinkach widoczna jest nawet liczebna przewaga aliantów. Na obszarze przyszłego frontu alpejskiego znajduje się 192 tys. włoskich żołnierzy i aż 320 tys. francuskich, w Trypolitanii/ Cyrenajce jest ich odpowiednio 90 tys. i 200 tys. Na granicy Cyrenajka/ Egipt naprzeciwko 45 tys. Włochów znajduje się 125 tys. Brytyjczyków, a we wschodniej części Morza Śródziemnego jest jeszcze gorzej (jedynie 18 tys. Włochów na Rodos). Nieco lepiej pod tym względem wygląda sytuacja w Etiopii ${ }^{106}$.

Marszałek Italo Balbo, zdeklarowany faszysta, a zarazem krytyk polityki Mussoliniego, mówił 30 maja niemieckiemu attaché wojskowemu Enno von Rintelenowi, że obawia się, iż bez dostaw lepszego sprzętu i uzbrojenia niż te, którym dysponuje, nie będzie w stanie utrzymać Libii, gdzie był namiestnikiem ${ }^{107}$. Z kolei marszałek Pietro Badoglio pięć dni przed publicznym ogłoszeniem przez Mussoliniego decyzji o interwencji wezwał do siebie Rintelena, by przestrzec go przed nadmiernymi oczekiwaniami wobec włoskich sił zbrojnych. Miał nadzieję, że wojna długo nie potrwa ${ }^{108}$. Duce zresztą sam na to liczył i uważał, że to ostatnia szansa, by Włochy niewielkim kosztem mogły zasiąść jako zwycięzca przy stole konferencji pokojowej.

10 czerwca, cztery dni przed wkroczeniem wojsk niemieckich do Paryża, Mussolini podczas przemówienia do zgromadzonego przed Palazzo Venezia tłumu ogłosił o przystapieniu do wojny po stronie Rzeszy (stan wojny miał obowiązywać od godzin porannych następnego dnia). Już pierwsze dni udziału faszystowskich Włoch w tej wojnie zapowiadały późniejsze kompromitacje o katastrofalnych skutkach. Niemal od razu Rzym utracił jedna trzecią floty handlowej, ponieważ nie zawiadomiono w porę kapitanów statków o konieczności powrotu. Spóźniona ofensywa włoska na froncie w południowej Francji przyniosła nader ograniczone rezultaty, a wkrótce Włosi utknęli, atakując francuskie umocnienia. Źle się działo również w Libii. Wszystko to stanowiło

104 Informował o tym radcę ambasady niemieckiej Anfusa. PAAA Berlin, Büro Staatssekretär, Italien 3, f. 493, Mackensen do AA, 4 VI 1940.

${ }^{105} \mathrm{~W}$ tej sprawie z nowszej literatury: J. Gooch, Mussolini and his Generals. The Armed Forces and Facist Foreign Policy, 1922-1940, Cambridge 2007, s. 450 i n.; M. Knox, Hitler's Italian Allies. Royal Armed Forces, Fascist Regime, and the War of 1940-1943, Cambridge 2000, s. 17 i n. W języku polskim ukazał się ostatnio przekład interesującego spojrzenia na włoski wysiłek wojenny: F. Joseph, Wojny Mussoliniego, tłum. K. Janicki, Warszawa 2012, podstawowa praca jest jednak nadal: G. Rochat, Wtochy na wojnie 1935-1943. Od podboju Etiopii do klęski, tłum. D. Jednorowski, Oświęcim 2018.

106 PAAA Berlin, Büro Staatssekretär, Italien 3, f. 493, Mackensen do Ribbentropa, 30 V 1940.

107 Ibidem, Rintelen i Mackensen do AA, 30 V 1940.

108 ADAP, D, VIII, dok. 387. 
dla Mussoliniego wielkie upokorzenie ${ }^{109}$, choć - jak się miało okazać - było to jedynie preludium do serii kolejnych katastrof militarnych. Ale mimo to apetyt Duce wobec pokonanej przez Niemców Francji okazywał się bardzo duży.

Tymczasem 16 czerwca w Bordeaux, dokąd po upadku Paryża ewakuował się rząd francuski, do dymisji podał się premier Reynaud. Następnego dnia na czele gabinetu staną marszałek Philippe Pétain, wybitny dowódca z Wielkiej Wojny, teraz głęboko przekonany o konieczności zaprzestania walki i celowości szukania możliwości kompromisowego porozumienia z Niemcami. Jednym z pierwszych posunięć nowego szefa rządu było wystapienie do narodu francuskiego z radiowym przemówieniem, głoszacym, iż w zaistniałej sytuacji nie pozostaje nic innego jak przystapienie do rozmów w sprawie warunków zawarcia rozejmu. Zwrócono się o to do Niemiec za pośrednictwem Hiszpanii; nie bez znaczenia był fakt, że Pétain pełnił do niedawna urząd ambasadora Francji właśnie w Madrycie.

18 czerwca w Monachium doszło do spotkania Hitlera i Mussoliniego, którym towarzyszyli Ribbentrop i Ciano - ten ostatni jeszcze poprzedniego dnia jako dowódca grupy bombowców bombardował miejscowości w północnej Korsyce. Głównym celem konferencji było oczywiście ustalenie warunków rozejmu z Francja. Na tle zachłannego Mussoliniego Hitler wykazywał w tej kwestii pewien umiar. Także Ribbentrop w rozmowie z Cianem przekonywał, że warunki podyktowane Francuzom powinny być umiarkowane ze względu na niebezpieczeństwo przejścia francuskiej floty wojennej na stronę brytyjska. Mówił też, że Berlin dąży do pokoju z Londynem, gdyż Imperium Brytyjskie nadal jest ważnym elementem światowej równowagi ${ }^{110}$.

Rozejm kładacy kres niemiecko-francuskim działaniom wojennym został podpisany 22 czerwca w Rethondes niedaleko Compiègne. Rozejm francusko-włoski podpisano dwa dni później i dopiero wtedy wstrzymano ogień na froncie niemiecko-francuskim, w akcie rozejmowym z 22 czerwca Niemcy uzależniły bowiem zaprzestanie walk od podpisania przez Francję rozejmu Italią.

Ze strony niemieckiej podkreślano, że jest to rozejm, a na ostateczne uregulowania o charakterze traktatu pokojowego przyjdzie pora później, gdy zmusi się Wielką Brytanię do porzucenia myśli o kontynuowaniu wojny. W podpisanych dokumentach pokonana Francja zobowiązywała się do nieprowadzenia jakichkolwiek działań nieprzyjaznych wobec Niemiec i Włoch. Ponad połowa obszaru Francji, wraz z Paryżem, miała być okupowana przez oddziały niemieckie; okupacja winna np. objąc cały pas północnego i zachodniego wybrzeża, aż po Półwysep Pirenejski, czyli do granicy z Hiszpanią. Włosi z kolei wymusili zdemilitaryzowanie Tulonu oraz korsykańskiego Ajaccio, a przede wszystkim demilitaryzację liczącego $50 \mathrm{~km}$ pasa terytorium Francji

\footnotetext{
${ }^{109}$ G. Ciano, op. cit., s. 535 (zapis z 21 VI 1940). O włosko-francuskich działaniach wojennych w czerwcu 1940 r. zob. H. Azeau, La guerre franco-italienne. Juin 1940, Paris 1967.

110 ADAP, D, IX, dok. 479. Krótko w: G. Ciano, op. cit., s. 534 (zapis z 18-19 VI 1940).
} 
przy swojej granicy. Terytoria zamorskie Francji miały pozostać wolne od okupacji i kontroli, choć niektóre porty w Afryce Północnej - również zdemilitaryzowane. W ten sposób udało się Niemcom nie dopuścić do opowiedzenia się francuskiej administracji kolonialnej po stronie nieuznającego kapitulacji ruchu Wolna Francja z gen. Charles'em de Gaulle'em.

Okoliczności, w jakich podpisywano oba traktaty pokojowe oraz podyktowane pokonanej Francji warunki rozejmu, unaoczniały Rzymowi, że odgrywa on rolę drugorzędną na tle potężnych Niemiec. Podpisanie przez Italię osobnego rozejmu z Francja było formą podkreślenia, iż Rzym prowadzi wojnę poniekąd osobna, równoległa do tej, jaką toczył Berlin. Włosi uznali, że tę ich podrzędność względem Berlina da się w relatywnie krótkim czasie przezwyciężyć poprzez zrealizowanie własnego programu. Ekspansja Italii miała kierować się nie tylko w stronę Bałkanów (a konkretnie Jugosławii i Grecji), lecz również w stronę posiadłości francuskich. Już w następnych miesiącach okazało się, że nadzieje włoskie były oparte na nierealnych założeniach, a ponoszącej klęskę za klęską Italii z pomoca pospieszyć muszą Niemcy ${ }^{111}$.

\section{Streszczenie}

Zwiąane z Niemcami układem sojuszniczym z maja 1939 (pact of steel) Włochy nie były przygotowane do wzięcia udziału w wojnie. Już 1 IX 1939 r. ogłosiły nieprzystapienie do wojny (zamiast terminu „neutralność” posłużono się formułą non belligeranza). Wywołało to w Niemczech krytyczne komentarze, chociaż Hitler i wraz z nim Ribbentrop podjęli starania, by ograniczyć narastające nastroje antywłoskie. Trudności w stosunkach bilateralnych pogłębiało zbliżenie między Berlinem a Moskwa, a zwłaszcza atak Związku Radzieckiego na Finlandię, który wywołał oburzenie we Włoszech. Poważne zastrzeżenia formułował wobec Niemiec m.in. minister Galeazzo Ciano (m.in. w przemówieniu z 12 XII 1939 r.), czego efektem było z kolei niezadowolenie w Berlinie. Krytykowano również postawę ambasadora Włoch w Berlinie Bernarda Attolica. Stosunki poprawiły się pod koniec zimy. 24 II 1940 r. podpisano nowy niemiecko-włoski układ gospodarczy, a 18 marca doszło do spotkania Hitlera i Mussoliniego na Brennerze. Po rozmowie z Duce kanclerz mógł być już pewny, że włoska non belligeranza długo już nie potrwa. Berlin nie uprzedził jednak swego sojusznika o ataku na Danię i Norwegię, podobnie jak o terminie uderzenia na Francję. Pod wpływem niemieckich sukcesów Mussolini (w nadziei, że działania zbrojne długo już nie potrwaja) był już całkowicie przekonany o konieczności przystapienia Włoch do wojny, co nastapiło 10 VI 1940 r. Jednak pierwsze dni udziału Włoch i pierwsze kompromitujące klęski pokazały, że sojusznik będzie dla Niemiec bardziej balastem niż wsparciem.

\section{Germany towards Italy in the First Phase of World War II (September 1939 - June 1940)}

Italy, bound with Germany by the alliance of May 1939 (Pact of Steel), was not prepared to take part in war. Already on 1 September 1939, the Italians announced their decision not

${ }^{111}$ Najlepsze kompleksowe ujęcie zob. Das Deutsche Reich und der Zweite Weltkrieg, t. III: Der Mittelmeerraum und Südosteuropa, Stuttgart 1984. 
to join the war (instead of the word 'neutrality', they used the term of non-belligeranza). This caused negative comments in Germany, although Hitler and Ribbentrop tried to restrain the increasing anti-Italian mood. The difficulties in bilateral relations were deepened by a rapprochement between Berlin and Moscow, and especially the Soviet Union's assault on Finland, which caused indignation in Italy. Serious reservations towards Germany were expressed among others by Minister Galeazzo Ciano (also in his speech of 12 December 1939), which in turn resulted in dissatisfaction in Berlin. Also the attitude of the Italian ambassador to Berlin, Bernardo Attolico, was criticised. The relations improved at the end of the winter of 1940 - on 24 February 1940 a new German-Italian economic agreement was signed, and on 18 March Hitler and Mussolini met at the Brenner Pass. After a conversation with the Duce, the chancellor was sure that the Italian non-belligeranza would not to last for a long time. However, Berlin informed the ally neither about the attack on Denmark and Norway, nor about the date of its assault on France. Under the influence of the German triumphs, Mussolini (in hope that military operations would not last long) was already convinced of the necessity for Italy to join the war, which took place on 10 June 1940. However, the first days of Italy's participation and its first embarrassing defeats confirmed that the Italian ally would be a burden to Germany rather than a support.

\section{Bibliografia}

Azeau H., La guerre franco-italienne. Juin 1940, Paris 1967.

Batowski H., Agonia pokoju i poczatek wojny. Sierpień - wrzesień 1939, Poznań 1984.

Cliadakis H., Neutrality and War in Italian Policy 1939-40, „Journal of Contemporary History" 1974, nr 9.

Das Deutsche Reich und der Zweite Weltkrieg, t. III: Der Mittelmeerraum und Südosteuropa, Stuttgart 1984.

Goeschel Ch., Mussolini and Hitler. The Forging of the Fascist Alliance, New Haven-London 2018.

Gooch J., Mussolini and his Generals. The Armed Forces and Facist Foreign Policy, 1922-1940, Cambridge 2007.

Joseph F., Wojny Mussoliniego, tłum. K. Janicki, Warszawa 2012.

Knox M., Hitler's Italian Allies. Royal Armed Forces, Fascist Regime, and the War of 1940-1943, Cambridge 2000.

Koszel B., Rywalizacja niemiecko-wtoska w Europie Środkowej i na Batkanach w latach 1933-1941, Poznań 1987.

Mack Smith D., Mussolini, Warszawa 1994.

Marzari F., Projects for an Italian-led Balkan Bloc of Neutrals, September-December 1939, „Historical Journal” 1970, nr 13.

Rauscher W., Hitler und Mussolini. Macht, Krieg und Terror, Graz-Wien-Köln 2001.

Rintelen E. von, Mussolini als Bundesgenosse. Erinnerungen des deutschen Militärattachés in Rom 1936-43, Tübingen-Stuttgart 1951.

Rochat G., Włochy na wojnie 1935-1943. Od podboju Etiopii do klęski, tłum. D. Jednorowski, Oświęcim 2018.

Schlie U., Kein Frieden mit Deutschland. Die geheimen Gespräche im Zweiten Weltkrieg 1939-1941, München-Berlin 1994.

Schütt W., Der Stahlpakt und Italiens „Nonbelligeranza” 1938-1940, „Wehrwissenschaftliche Rundschau" 1958, nr 8.

Siebert F., Italiens Weg in den Zweiten Weltkrieg, Frankfurt a. M.-Bonn 1962.

Sierpowski S., Niemcy $w$ polityce wtoskiej $w$ latach 1939-1940, w: idem, Studia $z$ historii Włoch XX wieku, Poznań 2012, s. 357-415. 
Sierpowski S., Stosunki polsko-wtoskie 1918-1940, Warszawa 1975.

Strzałka K., Między przyjaźniq a wrogościa. Z dziejów stosunków polsko-włoskich (1939-1945), Kraków 2001.

Weinberg G.L., Wizje zwycięstwa. Nadzieje ośmiu przywódców z czasów drugiej wojny światowej, tłum. R. Dymek, Warszawa 2007.

Żerko S., Niemiecka polityka zagraniczna 1933-1939, Poznań 2005.

Stanisław Żerko - prof. zw. dr hab., historyk i politolog, pracownik Akademii Marynarki Wojennej w Gdyni i Instytutu Zachodniego w Poznaniu. Zainteresowania naukowe: dzieje polityki zagranicznej Niemiec, historia stosunków polsko-niemieckich, geneza II wojny światowej. E-mail: stanislawzerko@gmail.com.

Stanisław Żerko - prof. dr hab., historian and political scientist, employee of the Polish Naval Academy in Gdynia and the Western Institute in Poznań. Research interests: history of German foreign policy, history of Polish-German relations, genesis of World War II. E-mail: stanislawzerko@gmail.com. 